\title{
On the Use of Modern Technological Technique for the Teaching of Anaang/Ibibio Tones
}

\author{
Itoro A. Michael \\ Department of Linguistics and Nigerian languages, University of Uyo, Nigeria
}

\begin{abstract}
Tone is an important feature of African tone languages. The aspect of tone identification, marking and analysis seem to be problematic in the teaching of most Nigerian languages; even in the existing orthographies apart from Yoruba and Tiv. The paper therefore proposed the use of modern technological aid for effective teaching of tones, with a view to providing insight into the analysis of Anaang/Ibibio tones. This study examined the relevance of the computer and software in language to show how the teacherslearners in a setting like Anaang/Ibibio stand to benefit from the use of modern technological devices in language research. The paper argues that teachers need to revise their methods in line with current technological trends for a better understanding of tone. This entails taking advantage of the double resources which the computer, and the access software provided, and adding to it the human intelligence. The position of the paper is that the computer is a more recent direction in language research and proved to be result oriented for the teaching/learning of tone. The application of modern technological device like software PRAAT and computer enhanced a feasibility study of the different patterns of tone. The use of spectrographic analysis actually converted the abstract sounds to ideal and visible sounds, thereby enhanced easy identification of the different tones. This paper therefore establishes a basis for the understanding of the relative tone/pitch forms of Anaang/Ibibio
\end{abstract}

Index Terms - tone, computer, software, technology

\section{INTRODUCTION}

Anaang/Ibibio are classified as tonal languages. The meanings and the production of the syllables, words, phrases and sentences are severely guided by the tonal pattern of the language. Therefore, the teaching of Anaang/Ibibio cannot be productive without a proper understanding of tone. In this modern technological era, there is an increased interest in the use of computer for teaching. This technology has extended to the teaching of language specifically, phonetics, lexicography, speech technology and descriptive linguistics. The reality of the mechanism of tones are still not understood even with the advances made in speech processing technology. However, with strides made in computer technology, lots more have been done on tonal investigation in Nigerian languages including Ibibio (Gibbon, Urua, Ekpenyong 2006, Urua 2007).

Nigeria is a pluri-lingusitic nation where only three languages; Hausa, Yoruba and Igbo are recognized as the major and official Nigeria languages alongside English (FGN 2006). Other Nigerian languages including Ibibio and Anaang therefore fall among the minority languages. Ibibio has been developed to a standard form and taught in primary, secondary, and tertiary institutions. The teaching of Anaang is only restricted to primary and adult education since it is yet to be developed to a standard level. Despite the rate of growth in the Ibibio language, the teachers as well as the learners of the language still find it difficult to tone mark correctly.

Tone is an indispensable distinctive feature of African tone languages. It contributes to both lexical and grammatical contrasts. Therefore any lexical or grammatical construct in African tone languages that is not properly tone-marked automatically leads to ambiguity in meaning. Consider the following pair of words from Ibibio.

1./ว́bว́y/ 'mosquito' and /د!́bว́y/ 'chief'

The misplacement of the tones on the segments can make one to address a 'chief' כ!́bว as 'mosquito' if the downstepped tone [ !] is omitted to produce /כ́bว́y/. It is therefore imperative to introduce a practical approach to the teaching of Ibibio/Anaang tones with a view to providing insight to the features of Anaang/Ibibio tones. This work therefore aims at establishing an instrumental method on how to identify tones and how to apply it in teaching using modern technological tools like software PRAAT and computer. Modern instructional technique is not equivalent to new techniques. It means improved and additional environmental settings to adapt to an old concept, in order to meet the demands of the $21^{\text {st }}$ century teaching techniques.

\section{A. Importance of the Problem}

Tone teaching//learning has been seen as a problematic area in the process of indigenous languages usage in Nigeria. One of the problems often identified is lack of material resources or teaching aid. Tone has been seen as a problematic phenomenon owing to its abstract nature. This abstractness actually attracted negative influence on the use of tone even in the approved orthographies of Nigerian languages. In the manuals of the orthographies of Nigerian languages 
(Okwuiduishu \& Salami 2000), except for Yoruba and Tiv, it has been unanimously agreed that tone marking on lexical as well as grammatical items should be ignored except for scholarly research. Various Nigerian language authors equally perceived the marking of tone as being cumbersome, clumsy and time consuming. To those scholars, tone marking can make graphology of Nigerian languages generally ugly to the sight, and overloads the graphological representation of the discourse with tone marks, especially if all the tones are indicated. This, accordingly, will make reading difficult and possibly discourage even the enthusiastic readers. In an attempt to support this view, Gudu(1990) clearly added that in the reading of scripts like Tiv, with observed tone marks, one has to do three things simultaneously to achieve meaning: to keep one eye on the grammatical relationship of the words, keep another eye on tone marks and observe the diacritics on the affected letters. This gives writers the authority to publish texts in Nigerian languages, including primers, without tone marking. By so doing, the teachers as well as the learners do not have reference materials for the learning of this abstract phenomenon. This equally makes the teachers to gloss over the teaching of tone in the language classroom. However, the argument that tone marks defaces pages of printed texts, is no argument. To leave tones unmarked in Anaang/Ibibio writing leads to a distortion from the true and essential structure into English. Tones help to ambiguate words, phrases and sentences, which otherwise look alike.

The second aspect is caused by lack of teaching aid. In Akwa Ibom State with well over four hundred primary and post primary schools, the government is only interested in the provision of laboratory and equipment for the teaching of only sciences, while materials/aid for language teaching is completely neglected. This, however affects the teaching of Anaang/Ibibio as subjects in schools.

However, if Anaang/Ibibio must be effectively taught in the Nigerian language classroom setting, where most of the teachers are not even efficient in tonal usage, identification and analysis, it is necessary for the teachers to go a step further to acquire computer knowledge in order to make effective use of the necessary technological teaching aid for language teaching, specifically for the analysis of tone in this era of technological development.

Teachers today are confronted with keeping abreast with rapid changes in science and technology. In the midst of school population and technological explosion, the teachers can no longer attempt to be the sole information giving instrument in the classroom. Secondly, the population explosion in schools is no longer favorable for traditional information/teaching in the classroom. Hence, the need for computer assisted instruction in schools as a tool for problem solving including language issues. The application of modern technology in the teaching of tone is effective in the production, acquisition, storage and retrieval of recorded data for use. This implies that the data stored for the practical teaching can easily be retrieved and used for subsequent teaching/learning exercises including research. Teachers are therefore encouraged to make use of computer/software for effective teaching of tones in African tone languages including Anaang and Ibibio.

Those who advocate the writing of Nigerian languages without tone marks are following the writing system of English. Tone languages are syllable-timed, while English is stress-timed and intonational. Therefore, tone marks cannot be applied for English writing system. The absence of tone marks in Nigerian tone languages is a distortion from the structure of the language to English, which invariably, results in the distortions of meanings. Consider the differences in the following pairs;
Ekpo 'ghost'
*Ekpo
Udo 'second male child' Mfon 'grace'
*Mfon
Ikpat 'foot'
*Ikpat

There is a distortion of the meanings of those words owing to the absence of tone on personal names as indicated with asterisks. The pronunciation of the pairs are presented below.

\begin{tabular}{|c|c|c|c|}
\hline Ékpó 'ghost' & Ùdว̀ 'second male child' & M̀fón 'grace' & Ìkpàt 'foot' \\
\hline Ékpò & *Údj & *Ḿfذ̀n & *Íkpàt \\
\hline
\end{tabular}

Tone marks have to be written because the structure of the language requires it for correct pronunciation, and meaning of elements of words, phrases and sentences. The point in this paper is not whether tones should be marked in Anaang/Ibibio, but on the techniques for the teaching of tones in the classroom. Tone is an integral part of grammar in tone languages. It is closely related to stress in intonational languages. The difference is that, stress has no fixed pattern for some languages. The application of modern technological device like software PRAAT and computer enhances a feasibility study of the different patterns of tone. It enhances precision on the exact height of each tone. Tone manipulation is made easy, feasible and accurately interpreted with spectrographic analysis. It provides empirical result to speech synthesis. The use of spectrographic analysis actually converts the abstract sounds to ideal and visible sounds, thereby enhances easy identification of the different tones.

It is against this background that this paper proposes an instrumental approach for the teaching of Anaang/Ibibio tones and suggests the use of modern technological devices like the computer and software PRAAT as a practical approach. The main aims of the study therefore include: To identify the different types of tones in Anaang/Ibibio, to classify and analyse these tones, to manipulate the different tones using sound spectrograph, and to provide a step by step practical procedure for the teaching of Anaang/Ibibio tones as a basis for effective language learning.

\section{B. Relevant Scholarship}

Lots of research has been carried out on the study of African tone languages. Crucial among the study in Nigerian languages include (Yoruba (Akinlabi 1985, Connell \& Ladd 1990) Hausa, Tiv (Sewuse 2011), Ibibio (Akinlabi \& 
Urua 1997, Connell 1987, Essien 1990, Urua 2001, 2007), Anaang, Efik , Ibibio, (Cook 1969, 1985, Connell 1987, Greenberg 1963, Udoh 1998, Diblugunaya \&Michael, 2003), Yala (Armstrong 1968), among others. Tone is defined as the use of contrastive, but relative pitch on a syllable. Tone is said to be an inherent property of the syllable in the sense that each syllable must have at least one tone. The tone bearing unit of the syllable is the vowel or syllabic segment. In other words, tones are marked on the peak constituent of the syllable. The pitches of voice in words keep changing in line with the variation of the tones on the syllable. Tone is represented with the following convention.

$(\mathrm{L})$ ow $=[$ '],$(\mathrm{H}) \mathrm{igh}=[$ '], (D)ownstepped high tone $=[$ ! ], Low-High cluster [`’], High-Low cluster [^]

The square brackets stand for phonetic realization, while slant slashes / / are used for phonemic realization of sounds. Tone is very crucial in lexical as well as grammatical formation. The pronunciation of grammatical as well as lexical items are determined by the tonal patterns of the language. At the same time, the semantics of the words are also determined by tones. In addition, the vital importance of tone in African tone languages is seen in the use of tone for communication of messages as explored in dances, poetry, riddles, tongue twisters, praise names among others (Urua 2001, Michael 2013). Therefore, the totality of African tone languages is based on the understanding of tone in order that a better analysis of the language is concluded effectively.

Previously, teaching was considered as a purposeful attempt by one (teacher) to impact knowledge or skills to another (learner). Within this context, the teacher role was that of the facilitator of learning; and the onus of learning, when properly guided rested more on the learners. Teaching however, involves ranges of activities aimed at assisting the learners to acquire knowledge, attitude values, habits and skills (Okwuenu 1996). In this vain, much blame is laid on the teacher who transmits knowledge to the learner. In order to avoid these blames, scholars however, focused and delineated instructional methods, strategies, techniques, for effective teaching. One of such methods include the cognitive apprentiship approach (Filmore 1976, Brown 1984, Carrell 1984, Schachter 1988) which is applied to simplify the task by scaffolding (extra help) and fading (diminishing the assistance) and allowing the students to complete the tasks through which the students are able to achieve mastery. In this regards, the teacher walks the students through the process in the practical participatory way, in which the instructor mind, and that of the students get automatically integrated together as that of experts. In this modern technological era, there is a shift from pure traditional teaching method to a more sophisticated technique including the application of computer and software for language teaching.

In linguistic studies, there is a change from quantitative to qualitative processing of language in a number of technologies. This includes the use of computer/software. Computer on its own cannot teach or conduct any research. It has to be manned by human. The computer is a product of human intellect because in any computer operation, there are powers of human intellects behind it. Computer is seen as a stool (Gibbon 2009), a complex artifact constructed by human. The computer does not and cannot think, therefore empirical and reliable result depends on the ability of the researcher to direct the computer. The use of computer to analyse data provides the foundation for yielding fast and quick speed. It maximizes the potential of the researcher, enforces criteria for consistency, completeness and soundness in this case, the teacher is able to avoid undergeneralisation and overgeneralization. It enhances the complementarities between machine and human and allows for cross fertilization benefit (Neufeld 1987, Sinclair 1997, Salamani 2008). The application of computer software to tone teaching triggers a practical design for both the teacher and the learner and enhances dependable output.

In the learning of tone, Ohala $(1978,1986,1995)$ and, Beckman (1986) proposed an experimental method as a well established method for the discovery of the physical correlate of the linguistic messages. Experimental phonology is viewed as a serial process, which include: making a claim, testing the claim, revise or abandon the claim, test the revised claim. Ultimately, in the series of analysis, there is plausibly a major acoustic-auditory component to the instrumental study. This continuous process following Ohala, would lead to a convergence of result which support a more confidently held beliefs.

\section{Previous Work}

A sample study of the aspect of tone had been conducted earlier with 300 level B.A. linguistics undergraduates from the University of Uyo. Findings proved that it was a bit easy to identify the level High \& Low tones, but very difficult for the subjects to identify or tone-mark the non-level tones like the downstepped high tone and tonal clusters. In the Linguistics Department of the University of Uyo, where Ibibio is offered as a Degree programme, it was discovered that the aspect of tone-marking was equally problematic to students on introduction. This problem was of course, arrested at some point with the introduction of a modern technological device including computer and software PRAAT for an instrumental teaching of tones. (Details on the sample procedure is presented in section III: A)The application of software PRAAT for the annotation of the pitch form showed that the two languages share the same number of tones. Spectrographic reading showed that Anaang as well as Ibibio have two level tones; High (H) and Low (L), plus a downstepped high tone (D), High-Low (HL) and Low-High (LH) clusters of tone, which were all phonemic. Since tone is an abstract phenomenon, it is more practicable and easy to identify and appreciate the relative pitches on segments when displayed on a computer/software. Consider the following items from Anaang/Ibibio.

a. Anaang examples 
A

1. ákpá 'water surface'

2. má 'love'

$\mathrm{H}$

3. ákpá 'he is death' $\mathrm{H} \mathrm{H}$

4. átèm 'he is cooking' $\mathrm{HL}$

5. ádèp míkp’ 'he bought something' $\mathrm{H}$ L $\mathrm{H}$ H

b. Ibibio Examples

6. éféRé 'he ran'

$\mathrm{H} \mathrm{H} \mathrm{H}$

7. éjèt 'he is washing'

$\mathrm{HL}$
B

àkpá 'first'

$\mathrm{L} \mathrm{H}$

mà 'finish'

$\mathrm{L}$

ǎkpá 'you are death'

LH H

ătèm 'he cooked'

LH L

ádép m mkpj 'did he buy something?'

$\begin{array}{lllllllllllll} & \mathrm{H} & \mathrm{H} & \mathrm{H}\end{array}$

éfèRé 'he is running'

$\mathrm{HL} \mathrm{H}$

èjèt 'you are washing'

L L

The difference in the pairs of the words is caused by the alteration of the tone on the initial segments. If there is no tone marking, it will not be easy to show the differences in meaning between these pairs, which look alike in spelling. It is tone that accounts for why $(4 a \& 6 b)$ are in the present and $(4 b \& 6 a)$ in the past time formation, why $(3 b \& 7 b)$ make use of a second person and ( $3 a \&$ a) a third person, why (5a) is a statement and (5b) a question. Other than tone, all the words in (1-2), structures in (3), phrases in (5-7) are otherwise alike in all aspects. In other words, they all have the same segments, but, different tones, which make a meaning difference. This proves that tones have to be fully marked in songs, stories, poems, proverbs, narratives, tongue twisters, riddles, in grammatical books and prose. A proper understanding of a tonal language is based on the understanding of the use and application of the tones in this technological era. This is made easier through the use of modern technological tools/computer software for teaching.

Method

Data was collected from two related languages of the Lower Cross family (Anaang and Ibibio) based on the standard variety. Twelve informants were purposefully selected from each of these language groups. A list of 200 Ibibio/Anaang lexical and grammatical items was administered to these informants. They provided the actual pronunciation which was recorded with a tape. The recorded items were then transferred into a computer system for speech synthesis/ annotation using software PRAAT. The recorded items were transcribed and classified. The data in turn was used as raw materials for the teaching of tones. The transcribed data was in turn stored as voice data or sound wave for tone annotation, identification, tone marking and manipulation using the 300 level B.A. Ibibio /linguistics undergraduates of the University of Uyo, for the sample study. The instrument used for this research were made available in the Linguistics/Faculty laboratory of the University of Uyo. This include; desktop computer, projector, pointer, power point, earphone, mic, and software PRAAT.

\section{Data Analysis And Discussion.}

The data presented covers lexical and grammatical tones in Anaang/Ibibio respectively. The data is presented in three levels of the syllable. These are: monosyllables, disyllables and polysyllables.
8. L $\mathrm{H}$
LL $\mathrm{HH}$
bj 'collect'
dí 'come'
nว่ 'give'
dá 'stand'
tèm 'cook'
má 'love'
9. LLLL
ibèrèdèm 'comforter'
ìnèmèsìt 'happiness'
ntùkùbè 'fost'
10. $\mathrm{HDH}$
ว́bว’́y 'chief'
11. Mixed lexical tones
LHHH
èmèm 'peace'
ímá 'love'
àkpókóró 'table'
12. Pairs of contrastive level tones
tèm L 'cook'
tém H 'cut grass'
$\mathrm{HHH}(\mathrm{H})$
ìbà 'two'
étó 'tree'
ùdì 'grave' íják 'fish'
úkpóhóré 'key'
úkárídém 'independence'
ékpémmé 'bottle'
m'!bว́k 'please'
HHL
LLHL
údárà 'star apple'
ṅtuèníbj̀k 'alligator pepper'
mèn L 'swallow'
mén H 'carry'
bòn $\mathrm{L}$ 'father a child'
bón $\mathrm{H}$ 'keep'

There is a contrast in the meaning of the words when the low tone on the vowel is substituted with a high tone. 
13. Grammatical tones

a.

àdémmé 'you are awake'

ákpeép mikpo' 'he taught'

àtó ú!ké 'where are you from?

Anaang

14. L

mà 'finish'

$\mathrm{H}$

dòp 'be quiet'

sé 'look'

keèt 'one'

15. LLL

ǹt’̀rjdj 'cassava'

bén 'carry'

dzít 'lock'

ìdòrènèn 'hope'

ìdàrètfit 'joy'

16. $\mathrm{HDH}$

ú!ké 'where'

17. Mixed lexical tone

HLHLH

m'kpùfióbùfíop 'butterfly'

18. Pairs of contrastive level tones
ýkáy 'charcoal'
ákpá 'water surface
n’kàn 'rib'
àkpá 'first'

$\mathrm{HHH}$

b.

ádémmé 'are you awake? (Question formation)

ákpèep m'kp' 'he is teaching. (Aspect)

átó ú!ké 'where is he from? (Person)

LL

èkà 'mother'

$\mathrm{HH}$

ènว' 'gift'

èkpèk 'chin'

j’káníká 'clock'

útuéníkán ' 'lamp'

ýkánáfán 'rust'

ú!mí 'this way'

19. Grammatical tones

ákà úfJkíbok 'he is going to the hospital'

áká úfJ́kíbכ'k? ' is he going to the hospital?

ágwèt mkpj you wrote something.

àkèré dié 'what is your name?

àgwèt mkpj' 'you are writing something'

ákèrè dié "what is his name?

\section{Procedure}

For the teaching/learning procedure, subjects were made to use data on lexical tones, pairs of contrastive lexical tones, and grammatical tones for the tone marking exercises. The students were able to mark lexical level tones on words with simple syllables only. They encountered some difficulties in the marking of words with mixed, and non level tones. Tones on grammatical items, phrases and sentences were completely avoided by the students. Based on this problem, the use of computer software was introduced as a practical guide. The subjects were made to go through a step by step instrumental design procedure for tone identification and annotation with the following guide:

- Using the data presented, identify the different tonal patterns in the language. Read the data aloud, and listen to the different pitches of the words. Segment the words into component syllables and produce the words aloud with closed lips, taking them syllable by syllable.

- Tone-mark the syllables from left to right based on the perceived relative pitches, read out the words a second time syllable by syllable to confirm the pitch variations.

- Read the words using the inbuilt mic., record them into a computer as sound document, using software PRAAT, and open the sound wave in the PRAAT for annotation of the data.

- Click on the window of the PRAAT and open the sound spectrograph for annotation. Click on the visible icon on the spectrograph and fix the boundary of each pitch by listening to the output using the earphone. Annotate the pitch of tone using sound spectrograph, click on the displayed visible section of the spectrograph again to listen to the pronunciation of the annotated pitches. Listen to the different pitches.

- Annotate the segments by drawing vertical lines across the spectrograph to segment each sound. Repeat the audio production to confirm the sound output. Trace the pitch pattern of the tones by marking the frequency (Fo) of the spectrographic reading as measured in 'decibel $(\mathrm{dB})$ '.

- Repeat the exercise with the same procedure using contrastive pairs of words, mixed level tones, lexical tones, grammatical tones, phrases, and concluded with sentence formation.

The practical session was repeated for two weeks at a duration of three hours per week. At the end of the practical session, it was established that Anaang/Ibibio have the same tonal pattern as proposed earlier by various scholars (Urua 2007, Michael 2009). The two languages have two level tones, a downstepped high tone and a cluster or a combination of the two level tones. The students were given a twenty item data on Ibibio for tone marking exercises to test their knowledge and effectiveness of their practical experiences. Based on their performances, the subjects were made to go through a step by step tone manipulation procedure starting with sequences of low tones, followed by sequences of high tones. This was concluded with the manipulation of contrastive pairs, lexical tones, phrases and sentences. This was repeated for one week. At the end of the practical, students were made to tone mark grammatical 
items of ten short sentences, to ascertain their post experience exposure and to determine the degree of the effectiveness of the practical technique. At the end, the subjects had no difficulty in identifying tones. The acoustic analysis of the annotation of few tones is as presented in (figures 1-8).

Each of the figures contains a wave form (top row), pitch trace (bottom row). Each column contains the different sounds of the segments. The distinction between each tone level is measured by the timing of the radiated frequency of the pitches on the right edge of the spectrograph. The annotation process is specifically guided by the practical procedure above. Each figure shows the physical display of the heights of each tone. The figure is a spectrographic or physical display of sounds on computer software PRAAT.

W ó

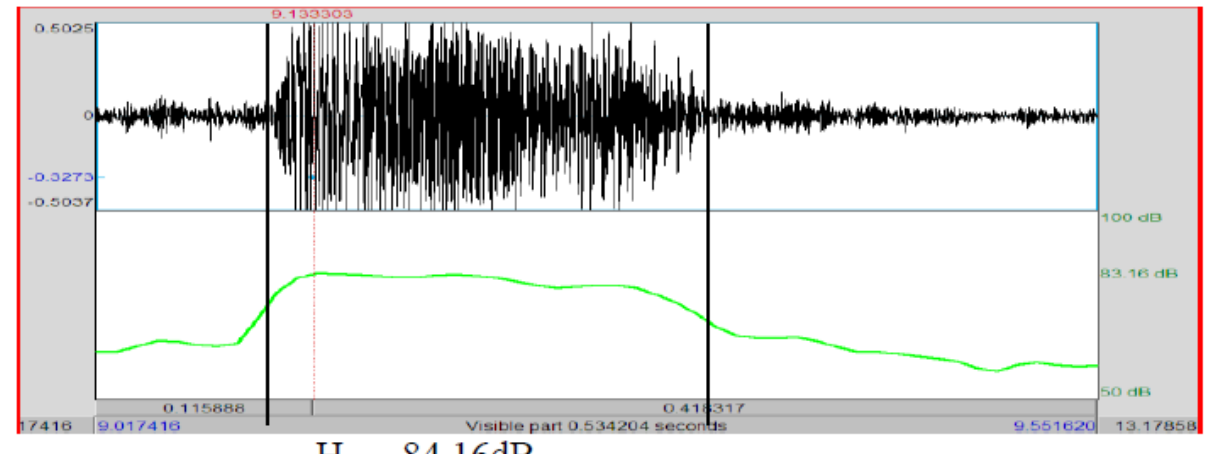

H $84.16 \mathrm{~dB}$

Figure 1. An acoustic analysis of a high tone; /wó/ 'tell' H

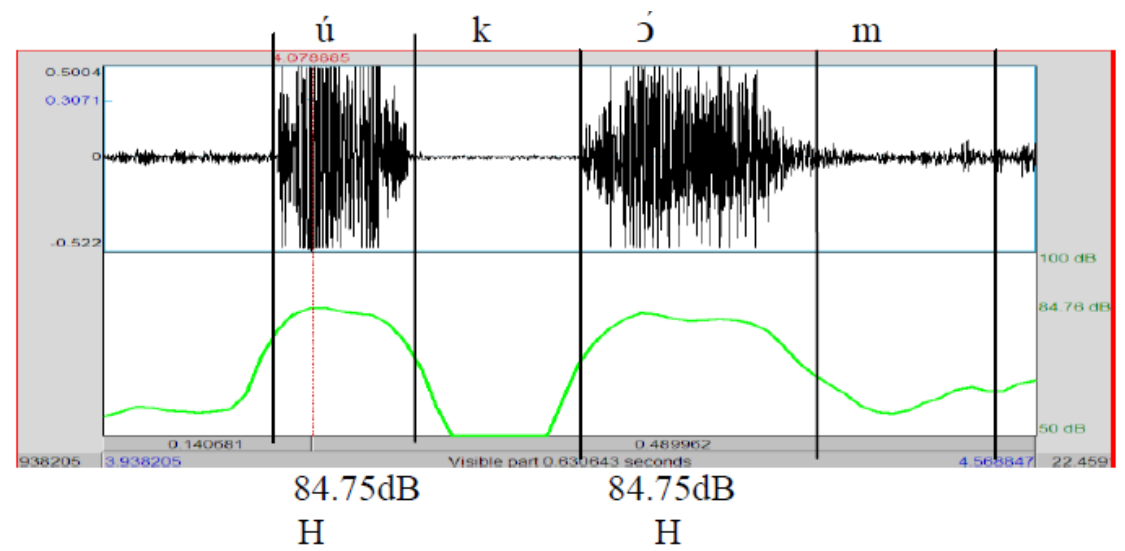

Figure 2. An acoustic analysis of two high tones; /úk j́ m/ 'plantain' $\mathrm{H}-\mathrm{H}$

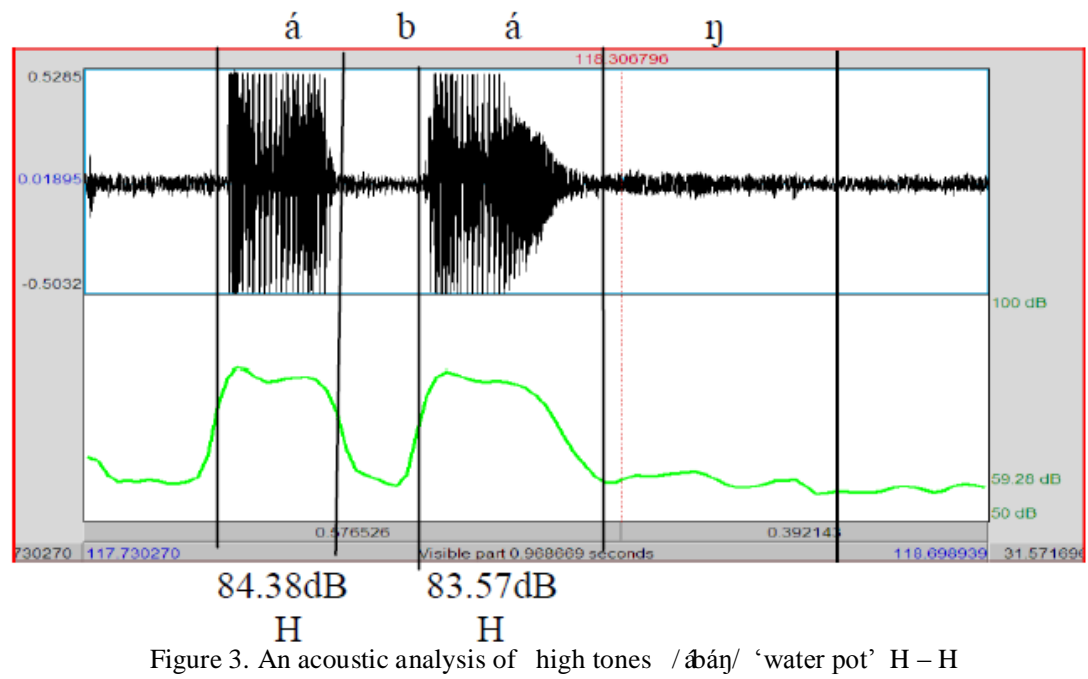

Figure 3. An acoustic analysis of high tones /ábán/ 'water pot' $\mathrm{H}-\mathrm{H}$ 


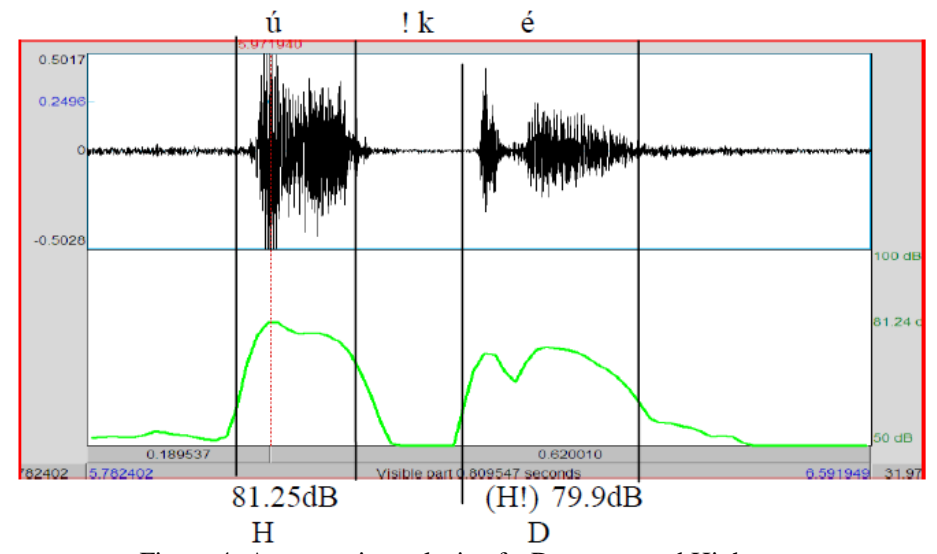

Figure 4. An acoustic analysis of a Downstepped High tone; /ú-!kó/ 'yonder' H!H

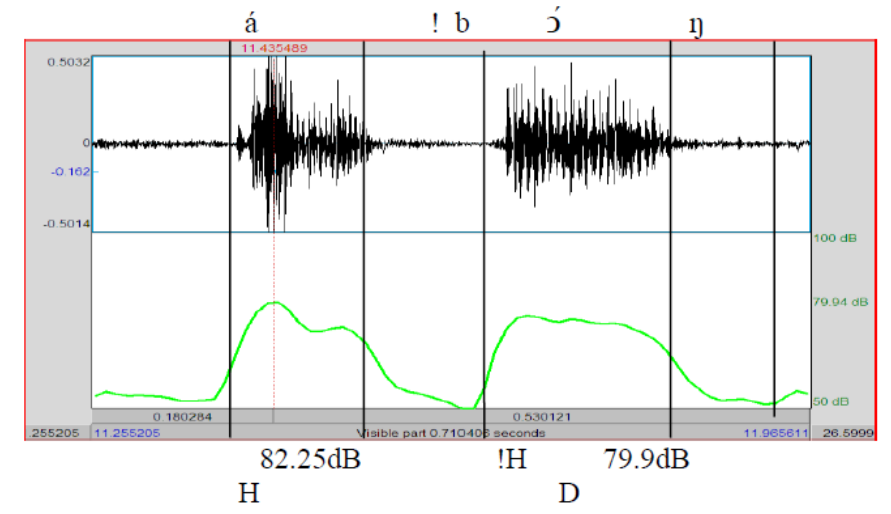

Figure 5: An acoustic analysis of / á!b j’ y/ 'Chief’ $\mathrm{H}-$ ! H

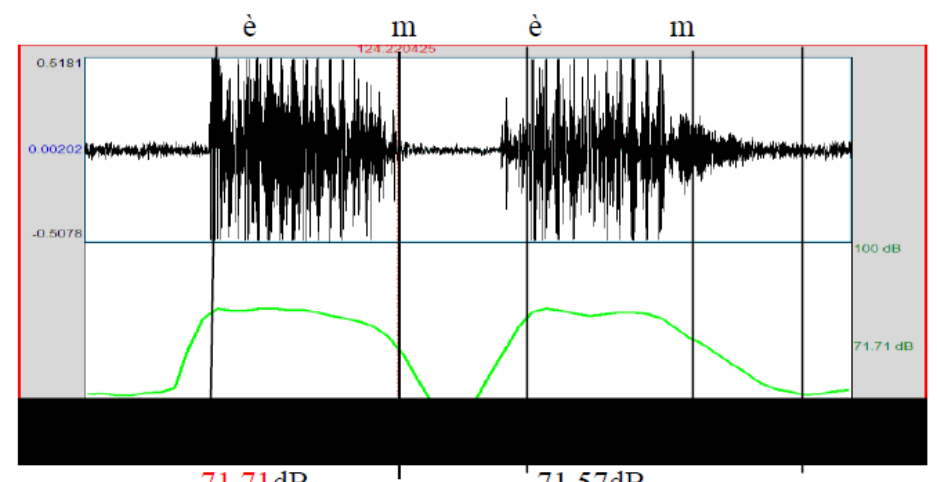

L

L

Figure 6: An acoustic analysis of level low tones; /èmèm/ 'peace' L L

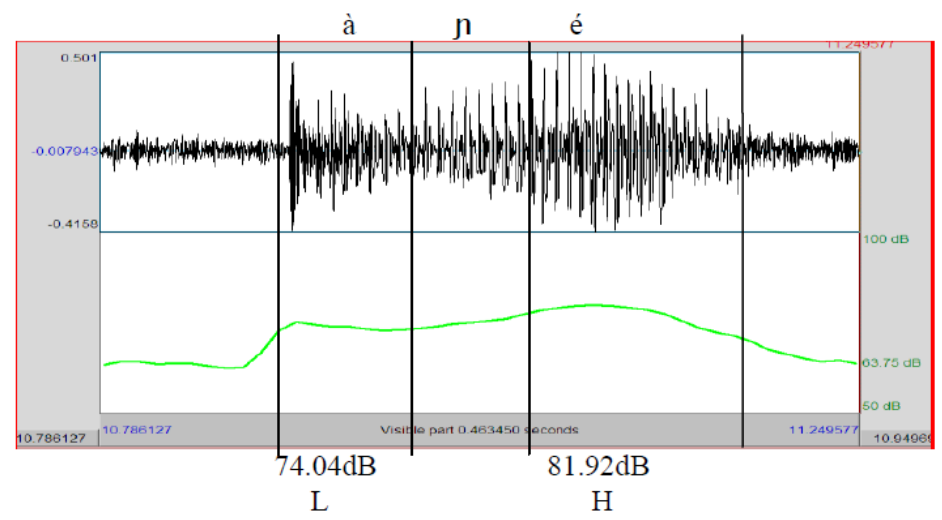

Figure 7: An acoustic analysis of mixed low and high tones; /àné/ 'him/her' LH 


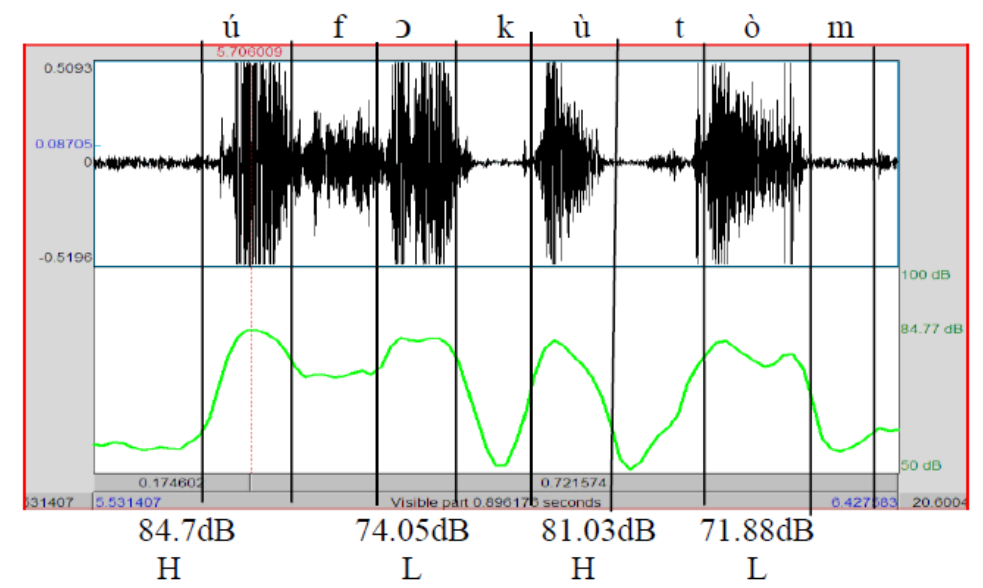

Figure 8. An acoustic analysis of [úfjkútòm] 'office'H-L-L-L-L

$$
\text { /úfJk/ + /útóm/ } \rightarrow \quad \text { [úfjkútòm] }
$$

The spectrographic analysis of the tones is as follows;

The black zig zag pattern on the first row of the spectrograph represents the acoustic patterns of sound wave. Vowels have dense darker wave form than the consonants. The lemon colour line with hills/valleys structure is the pitch variations of voice that determine the actual heights of each tone. The pitch variation of the tone is presented in fundamental frequency (Fo) measured in decibel (dB) or Hertz $(\mathrm{Hz})$. The vertical lines show the boundary of each sound. The spectrographic reading is from left to right. The last dark row is the visible part of the spectrograph.

The reading of each spectrograph is as follows;

- Figure (i) presents an acoustic analysis of a level high tone. There is an uprising of the pitch level from the valley. The rising does not fluctuate, rather it has a level trace just like a plateau. The level nature of the acoustic form of the pitch makes the tones in Anaang/Ibibio to qualify for 'level tones'. The acoustic reading shows that the pitch level of the tone stood at $84.31 \mathrm{~dB}$.

- Figures (2\&3), show two level high tones respectively. Observe also that the column of the tone on the vowels have a kind of plateau pattern each, with an average pitch height of $83-84 \mathrm{~dB}$.

- The next figures; (4\&5) present acoustic analysis of a downstepped high tone. The initial tone of each of the figures is a high level tone with a frequency of $81-82.25 \mathrm{~dB}$ respectively. The tone on the second syllable is not as high as the initial high tone. It has been downstepped, but not low enough to be qualified for a low tone and not high enough to be qualified for a high tone. The acoustic analysis shows that downstepped high tones have a pitch level of $79.9 \mathrm{~dB}$

- The spectrograph in (6) represents level low tones. The data in / èmèm/ / has two level tones. The pitch reading is at $71 \mathrm{~dB}$, which is lower than the pitches of high and downstepped tones. Therefore, the acoustic height of the tone in / èmèm/ / is qualified for a low tone. Observe that there is a kind of plateau lines in the column where we have vowels in the spectrograph, while consonant sounds have a kind of valley lines, which indicate the absence of tones on consonant sounds. This in essence shows that tones are marked on vocalic sounds and not on the consonants. The pitch level in / èmèm// is between $71 \mathrm{~dB}$ and $72 \mathrm{~dB}$.

- The next diagram represents low and high mixed lexical tones. The initial syllable has an average acoustic reading of $74 \mathrm{~dB}$ representing a low tone, while the second syllable has an average point of $81 \mathrm{~dB}$ indicating a high tone.

- The last figure (8) is a representation of mixed phrasal tones. The acoustic analysis shows an average reading of $81 \mathrm{~dB}-84 \mathrm{~dB}$ for high tones and $71 \mathrm{~dB}-74 \mathrm{~dB}$ for low tones.

A summary of the acoustic reading for the three tones is as follows:

$$
\begin{array}{lll}
\mathrm{H} & \mathrm{L} & \mathrm{D} \\
81 \mathrm{~dB}-84 \mathrm{~dB} & 71 \mathrm{~dB}-74 \mathrm{~dB} & 78 \mathrm{db}-79 \mathrm{~dB}
\end{array}
$$

The spectrographic displays of the different tonal patterns therefore indicate that high tones should have a pitch of $81 \mathrm{~dB}$ and above, downstepped high tone $78-79 \mathrm{~dB}$. The pitch level that falls below $75 \mathrm{~dB}$ is a low tone. With a spectrographic analysis, it is possible to visualise the pitches of tones, describe precisely the relative heights of the tones based on the relative frequency, which is calculated in decibel $\mathrm{dB}$. The acoustic analysis shows that Anaang/Ibibio qualified to be classified as registered tone languages with terracing level systems. A register tone language has level pitches relative to one another with little or no gliding (Urua 2001, Welmars 1973).

Anaang/Ibibio attest two level tones: high, Low plus a downstepped high. The tones are all contrastive. The downstepped high tone is also contrastive as the omission of the downstepped symbol in /m! bók/ 'wrestling can be mistaken for $/ \mathrm{m} ! \mathrm{b} \mathrm{j}_{\mathrm{k}} /$ 'peace' in Ibibio. The application of computer software for the teaching/learning of tone is yet to be fully utilized by researchers. The poor attitude towards the marking of tone in scripts even in paper presentation at 
conferences by scholars presents the actual state of the position of tone in language learning. They see tone marking as an uninteresting and cumbersome venture specifically as the conventional computer key board does not have keys for the different tones. Therefore a fair knowledge of the application of computer is imperative for an effective research on tone. The application of computer softwarePRAAT is a commendable stride to the teaching/learning of tone. The acoustic display of tone on the spectrograph enables both the teacher and the learner to visualise the tone, listen to, and perceive the pitches, and do lots of other interesting things like tonal manipulation, analysis and classification and also say precisely the unit of segment for tone placement. For the linguists to effectively develop Nigerian languages, the understanding of the intricacies of tone is imperative. It is believed that when the approach for tone/language teaching changes in line with the new technological trends, language research and teaching outcome on tone will become effective and relevant.

Grammatically, Anaang/Ibibio tones can mark grammatical functions like tense, aspect, persons and question formation. Tone is an important phenomenon in African tone languages. The understanding of tone enhances correct and ease of pronunciation, meaning and vocabulary development. The teaching of the grammar as well as the literature in tonal languages cannot be successful without tone. The aspects of both reading and writing in tonal languages are severely guided by tone. Therefore the marking of tones in published texts and research works should not be glossed over by scholars and writers.

\section{CONCLUSION}

This study examines the advent of the computer in language to show how the teachers/learners in a setting like Anaang/Ibibio stand to benefit from the use of computer in language research. The paper argues that teachers need to revise their methods in line with current technological trends for a better understanding of tone. This entails taking advantage of the double resource which the computer, and the access software provide, and adding to it the human intelligence. The position of the paper is that the computer is a more recent direction in language research and proved to be result oriented for the teaching/learning of tone.

Basically, with the introduction of the use of computer in the school curriculum, language teachers should make extra effort to apply their knowledge of computer to linguistic computing as a step to the understanding of speech synthesis. Tonal annotation is an aspect of speech synthesis which requires competent knowledge of computer use, therefore language teachers have to be computer literate. It has generally been affirmed that the combination of the computer, and its access software has revolutionized language research and taken it to heights previously unimagined because of the capability of the computer to perform research tasks in ways beyond the human ability. The use of the computer is complementary to the human researcher and enables the optimization of research value and time since the computer can access those features that are too abstract in texts, sees beyond the human eye, stores and handles very expansive data, and works with incredible and reliable result and speed. The application of modern technology in the teaching of tone is effective in the production, acquisition, storage and retrieval of recorded data for use. This implies that the data stored for the practical teaching can easily be retrieved and used for subsequent teaching/learning exercises including research. Teachers are therefore encouraged to make use of computer/software for effective teaching of tones in African tone languages including Anaang and Ibibio.

In conclusion therefore, there are many challenges for the linguists, the language teachers and for the learners. To make teaching effective, to make sustainable learning, to benefit effectively from language research, linguists, teachers and the research communities need to take advantage of the resource of the computer and the access software. Instrumental study of language gives priorities, reduces exceptions and liberates the creative mind in tonal analysis. When the methods of language instruction changes in line with current technological trends, indigenous language teaching will become relevant and productive.

\section{REFERENCES}

[1] Akinlabi, A. M. \& E. E. Urua (1997). Tone in Ibibio verbal reduplication. Proceedings of the $2^{\text {nd }}$ World Congress of African Linguistics.

[2] Akinlabi, A. M. (1985). Tonal underspecfication in Yoruba tone. PhD. Thesis, University of Ibadan.

[3] Armstrong, R. G. (1968). Yala (Ikom): a terraced level language with three tones. Journal of West African Languages 5, 4958.

[4] Beckman, M. A. (1986). Stress and non stress accent. Dordrecht: Foris Publication.

[5] Brown, H.D. (1984). Principles of language learning and teaching. New Jersey: Prentice Hall.

[6] Carrell, P. L. (1984). Evidence of formal schema in second language comprehension. Journal of language learning 34: $3.17-$ 30

[7] Connell, B. A. \& D. R. Ladd (1990). Aspects of pitch realization in Yoruba. Phonology 7, 1-30.

[8] Connell, B. A. (1987). Temporal aspects of Ibibio labiovelar stops. Work in Progress 20, 22-35

[9] Cook, T. L. (1969). The pronunciation of Efik for speakers of English. Bloomington: Indiana University.

[10] Cook, T. L. (1985). An integrated phonology of Efik. PhD Dissertation, University of Leiden, Leiden, The Netherlands.

[11] Diblugunaya, A. \& I. Michael, (2003). Tones in Anaang. In Ndimele, O.M. (ed.), In the linguistic paradise. A festschrift for Emenanjo. Aba: NINLAN, 234-247.

[12] Essien, O. E. (1990). A grammar of the Ibibio language. Ibadan: University Press. 
[13] FGN. (2006). National Policy on Education (NPE). Abuja: NERDC.

[14] Filmore, L. W. (1976). The second time around: cognitive and social strategies in second language acquisition. PhD. Dissertation. Stanford University.

[15] Gibbon, D. (2003). Computational linguistics in the workable efficient language documentation paradigm. In Gerd Willee etal (eds.), Computer linguistic: was geht was komnt? St. Augusttine: Gardez! Verlang 75-80

[16] Gibbon, D. (2009). Why should linguist compute? Journal of linguistics, languages and literature 5, 2; 1-13.

[17] Gibbon, D. E. E. Urua, \& M. Ekpenyong. (2006). Problems and solutions in African tone language text-to-speech. In Justins, Roux (ed.). Proceedings of the multilinguistic conference. Stellenbosch, South Africa. 34-59.

[18] Greenberg, J. H. (1963). The languages of Africa. The Haugue: Mouton \&Co.

[19] Gudu, G. A. (1990). Problems and prospects of the minority language literature in Nigeria. The case of Tiv phone literature. In Emenanjo, E. (ed.), Multilingualism: minority languages and language policy. Agbor: Central Books. 34-43.

[20] Michael, I. (2009). The syllable structure of the Anaang language. Ph.D. Thesis, university of Ibadan, Ibadan.

[21] Michael, I. (2013). A socio-phonological description of Anaang proverb-riddles. Journal of language and literature Vol 4,2. 45-57

[22] Neufeld, (1987). A handbook of technical communication. New Jersey: Prentice Hall.

[23] Okwuenu, J. (1996). Teaching profession in Nigeria. In Ogwo, B. A. (ed.) Preparing instructional material for multilingual teaching. Agbor: Central Books. 22-37.

[24] Ohala, J. (1978). The production of tone. In Fromklin, V. (ed.), Tone: a linguistic survey. New York: Academy Press. Pp 5-39.

[25] Ohala, J. (1986). Experimental phonology. Orlando: Academy Press

[26] Ohala, J. (1995). Experimental Phonology. In Goldsmith, J. (ed.) The handbook of phonological theory. Blackwell: Oxford. $712-723$

[27] Okwuiduishu, U. \& O. S. Salami (eds.) (2000). Orthographies of Nigerian Languages, Manual Vii. Abuja: NERDC.

[28] Oyeleye, L. (2005). The new linguistic order: A critical examination of the impact of globalisation on the English language in Nigeria. In M. Olateju \& L. Oyeleye (Eds.), Perspectives on language and literature, (pp. 3-14). Ife: OAU Press.

[29] Salmani Nodoushan, M. A. (2008). The quantum human computer (QHC) hypothesis. Journal of Educational Technology, $4(4), 28-32$.

[30] Sewuse sar, V. (2011). Tone marking as an aid to correct pronunciation of words in Tiv. In Nigerian languages studies Vol. 2 No.II. $42-46$

[31] Sinclair, J. (1997). Corpus evidence in language description. In A. Wichmann, S. Fligelstone, T. McEnery \& G. Knowles (Eds.), Teaching and language corpora, (pp. 27-39). London: Longman.

[32] Schachter, J. (1988). An error in error analysis. Language learning 24, 19; 205-214

[33] Udoh, I.I. (1998). The effects of duration on intonation of Anaang learners of English. Ph.D. Dissertation, University of Calabar, Calabar.

[34] Urua, E.E. 1997. A phonetic analysis of Ibibio tones. Journal of West African languages, Vol. XXX, 1, 15-26

[35] Urua, E.E. (2001). Ibibio phonetics \& phonology. South Africa: CASAS.

[36] Urua, E. E. (2007). Ibibio phonetics \& phonology. ( $2^{\text {nd }}$ edn.) . Prot Harcourt: M\&J Grand Orbit.

[37] Welmars, W. (1973). African language structures. Berkeley: University of California Press.

Itoro A. Michael is a holder of a PhD. degree in Linguistics in 2009, from the University of Ibadan, Nigeria. Her areas of interest are: Phonetics/phonology, Sociolinguistics, Descriptive and Documentary Linguistics.

She lectures with the University of Uyo, Nigeria and has several paper publications to her credit. She is the co-author of 'The Orthography of the Anaang language'. Calabar: Anaang Community, (2001).

Dr Michael is a member of many learned societies. She is a Fellow of the African Humanities Programme/American Council of Learned Societies (FAHP/ACLS). 